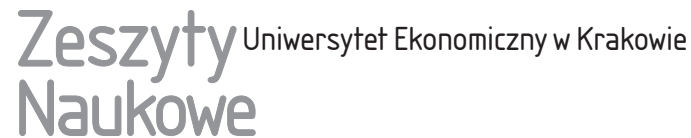

\section{Warunki i decyzje mieszkaniowe seniorów na lokalnym rynku nieruchomości}

\section{Streszczenie}

Zgodnie z prognozami demograficznymi postępujące zjawisko starzenia się społeczeństwa wymusi szereg zmian na rynku mieszkaniowym. Coraz częściej podejmuje się różnego rodzaju dyskusje na tematy związane z zapewnieniem odpowiedniej opieki osobom starszym oraz dopasowaniem oferty mieszkaniowej do preferencji i oczekiwań seniorów, jak również na tematy związane z decyzjami dotyczącymi ewentualnej zmiany warunków mieszkaniowych i wyboru nowego miejsca zamieszkania. Niniejszy artykuł wpisuje się w nurt tej dyskusji, jego celem jest bowiem przedstawienie sytuacji mieszkaniowej osób starszych. W tym celu wykorzystano badania kwestionariuszowe na temat sytuacji mieszkaniowej przeprowadzone wśród seniorów.

Uzyskane rezultaty badań świadczą o tym, że seniorzy pragną jak najdłużej pozostawać w swoich domach, korzystając z opieki ze strony opiekunów formalnych bądź nieformalnych. Ponadto stosunkowo młodsze grupy seniorów cechuje większa otwartość na osiedla mieszkaniowe przeznaczone dla seniorów oraz mieszkanie z innymi ludźmi w zamian za opiekę, zaś seniorzy mieszkający samodzielnie w większym stopniu akceptują zamieszkiwanie w domu spokojnej starości - prywatnym lub państwowym.

Łukasz Strączkowski, Uniwersytet Ekonomiczny w Poznaniu, Wydział Zarządzania, Katedra Inwestycji i Nieruchomości, al. Niepodległości 10, 61-875 Poznań, e-mail: lukasz.straczkowski@ue. poznan.pl

Marcin Boruta, Uniwersytet Ekonomiczny w Poznaniu, Wydział Zarządzania, Katedra Inwestycji i Nieruchomości, al. Niepodległości 10,61-875 Poznań, e-mail: marcin.boruta@ue.poznan.pl 
Słowa kluczowe: seniorzy, rynek mieszkaniowy, starość demograficzna, mieszkalnictwo senioralne.

Klasyfikacja JEL: R31.

\section{Wprowadzenie}

Przez wzgląd na zachodzące współcześnie przemiany demograficzne ludności Polski seniorzy stanowią na gruncie nauk społeczno-ekonomicznych coraz częściej badaną grupę. Rosnące zainteresowanie osobami starszymi skutkuje powstawaniem wielu nowych koncepcji, postulatów i rozwiązań odnoszących się do różnych aspektów ich życia. Prowadzenie kompleksowej polityki senioralnej wymaga bowiem zaangażowania w wielu obszarach, do których można zaliczyć rynek pracy, pomoc socjalną, opiekę długoterminową, a także mieszkalnictwo. Dla wypracowania spójnej koncepcji polityki senioralnej niezbędna jest jednak diagnoza sytuacji obecnej, w tym i mieszkaniowej.

Warunki mieszkaniowe mają zasadniczy wpływ na jakość życia człowieka. W przypadku seniorów wpływ ten zdaje się wzmacniać fakt, że osoby te spędzają w domu i jego najbliższej okolicy większą część dnia niż ludzie należący do pozostałych grup wiekowych. Powszechnie uważa się także, że seniorzy, mimo że odczuwają pewne niedogodności i zgłaszają bariery i problemy, nie są skłonni do zmiany miejsca zamieszkania i są zadowoleni ze swojego lokum oraz otoczenia.

Mając powyższe na uwadze, celem niniejszego opracowania jest prezentacja sytuacji mieszkaniowej osób starszych. Artykuł został opracowany na podstawie studiów literatury przedmiotu oraz badań kwestionariuszowych przeprowadzonych z wykorzystaniem ankiety audytoryjnej wśród seniorów w większości regularnie uczęszczających na zajęcia organizowane w tzw. klubach seniora (metodykę badań zaprezentowano w dalszej części opracowania).

\section{Współczesne przemiany demograficzne ludności Polski}

Rozwój demograficzny charakteryzuje się ciągłością, w której kolejne fazy następują po sobie w konsekwencji wcześniejszych zmian. Współczesne przemiany demograficzne są zatem wynikiem zjawisk i procesów przeszłych. Demograficzne starzenie się ludności Polski nie jest procesem nieoczekiwanym i zaskakującym, dla wielu zaskakujące okazały się jednak jego rozmiary. 
Do najważniejszych przyczyn starzenia się ludności Polski zalicza się:

- wydłużanie się czasu trwania życia ludzkiego',

- procesy migracyjne ${ }^{2}$,

- zbyt niski współczynnik dzietności ${ }^{3}$.

Dane jednoznacznie wskazują, że obecnie Polska znajduje się na etapie drugiego przejścia demograficznego. Ewoluował model rodziny - z mieszczańskiego w stronę zindywidualizowanego. Nowo powstały wzorzec bazuje na osobistych aspiracjach człowieka. Odchodzi się od modelu rodziny wielodzietnej oraz wielopokoleniowej.

W celu prezentacji i oceny etapu rozwoju demograficznego danej populacji można posłużyć się wieloma miernikami. Do najpowszechniej stosowanych zaliczyć można współczynnik starości ${ }^{4}$. W świecie nauki nie ma jednak zgody co do czasu wyznaczającego dolny próg starości jednostki. Dzieje się tak, ponieważ istniejąca granica między dojrzałością a starością jest obecnie bardzo elastyczna i rozmyta (Rysz-Kowalczyk i Szatur-Jaworska 2004, s. 231). Najczęściej spotykaną koncepcją jest ustalanie początku starości na podstawie wieku metrykalnego (Szukalski 2012, s. 94). W praktyce stosuje się też podejścia traktujące na równi kobiety oraz mężczyzn, zaliczając ich do grona seniorów, gdy osiągną wiek 60 bądź 65 lat (Rosset 1956, s. 61-73; Król 2014, s. 13). Mając na uwadze silnie zróżnicowanie wewnętrzne populacji osób starszych, badacze coraz częściej dokonują dalszego, już wewnętrznego podziału populacji osób starszych na poszczególne grupy. W raportach Organizacji Narodów Zjednoczonych powszechne jest stosowanie wewnętrznego podziału seniorów na dwie grupy: osoby w wieku 65-79 lat oraz osoby w wieku 80 lat i więcej.

Posługując się współczynnikiem starości, można stwierdzić, że według stanu na dzień 31 grudnia 2015 r. udział ludności w wieku 65 lat i więcej w ogóle ludności Polski wynosił 15,8\%, z czego 4\% stanowili seniorzy w wieku 80 lat i więcej. W stosunku do 1989 r. zanotowano wzrost wartości analizowanego wskaźnika o 5,8 p.p. dla całej populacji seniorów oraz wzrost o 2 p.p. dla grupy osób najstarszych, tj. w wieku 80 lat i więcej. Prognozy Głównego Urzędu Statystycznego wskazują, że w 2050 r. niemal co trzeci Polak osiągnie wiek co najmniej 65 lat. Szacuje się, że współczynnik starości wyniesie wówczas 32,7\%, z czego

${ }^{1}$ W latach 1998-2015 przeciętny czas trwania życia w Polsce wydłużył się o 4,7 lat (Tablice trwania życia... 2016).

${ }^{2}$ Nieprzerwanie od 1960 r. saldo migracji zagranicznej Polaków na pobyt stały jest ujemne (Migracje zagraniczne... 2016).

${ }^{3}$ Współczynnik dzietności od wielu lat kształtuje się na poziomie niezapewniającym prostej zastępowalności pokoleń.

${ }^{4}$ Współczynnik starości obliczany jest jako stosunek liczby osób starych do ogółu ludności danej populacji. 
10,4\% stanowić będą osoby w wieku 80 lat i więcej (Sytuacja demograficzna... 2014, Rocznik demograficzny... 2016). Posługując się skalą zaproponowaną przez E. Rosseta, stwierdzić należy, że Polska znajduje się w chwili obecnej w fazie mocno zaawansowanej starości demograficznej (Rosset 1956, s. 61-73). Ponadto najwyższą dynamiką zmian cechuje się grupa osób w wieku co najmniej 80 lat. Zjawisko to demografowie określają mianem podwójnego starzenia się ludności (Deniszczuk 2001, s. 10). Mając na uwadze powyższe, autorzy niniejszego opracowania skoncentrowali swą dalszą uwagę właśnie na grupie najstarszych seniorów.

\section{Specyfika seniora na rynku nieruchomości}

Wiedza na temat warunków mieszkaniowych osób starszych pochodzi w Polsce w głównej mierze z Narodowego Spisu Powszechnego 2002 (Narodowy Spis Powszechny... 2003), raportu Warunki mieszkaniowe gospodarstw domowych i rodzin 2002 (2003) oraz kompleksowego opracowania pt. Mieszkania starszych ludzi w Polsce. Sytuacja i perspektywy zmian (2001). Przeprowadzone wówczas badania wykazały, że warunki mieszkaniowe osób starszych są na ogół gorsze niż przeciętne warunki mieszkaniowe w Polsce. Ponadto najgorsze warunki mieszkaniowe mają osoby należące do grupy osób najstarszych, w wieku co najmniej 80 lat. Wiele z nich zajmuje mieszkania wybudowane przed $1939 \mathrm{r}$. Cechują się one na ogół dużą powierzchnią, lecz niskim standardem i złym stanem technicznym. Często brakuje w nich centralnego ogrzewania, nierzadko także łazienki. Przedstawione we wskazanych opracowaniach tezy mogą okazać się jednak szybko nieaktualne, ponieważ sytuacja mieszkaniowa ulega nieustannym zmianom, a przyczyn należy doszukiwać się w przyrostach i ubytkach mieszkań oraz zmianach składu grupy osób w starszym wieku. Odchodzą najstarsi seniorzy zajmujący relatywnie najstarsze mieszkania, zaś w wiek 80 lat wchodzą osoby z mieszkań wybudowanych w okresie PRL. Obecnie mamy do czynienia $\mathrm{z}$ istotną luką informacyjną w kwestii aktualnych warunków mieszkaniowych seniorów. Potwierdzeniem występujących nieścisłości mogą być wyniki badań przeprowadzonych przez Centrum Badania Opinii Społecznej w 2010 r. na próbie 11164 osób w wieku co najmniej 60 lat. Zaledwie 6\% ankietowanych uznało wówczas swoje warunki mieszkaniowe za „raczej złe”, zaś $2 \%$ za „bardzo złe" (Obraz typowego Polaka... 2010, s. 3). Z badań CBOS-u wynika ponadto, że $74 \%$ osób starszych prowadzi swoje gospodarstwa domowe samodzielnie, z czego $38 \%$ to osoby samotne, zaś $36 \%$ żyje w związku. Zaledwie $15 \%$ respondentów zamieszkuje wraz ze swoimi dziećmi lub rodzicami, a $11 \%$ z dziećmi, wnukami bądź innymi członkami rodziny (Obraz typowego Polaka... 2010, s. 2).

Najbardziej aktualne opracowanie, obejmujące m.in. aspekty mieszkalnictwa, stanowi monografia pt. Aspekty medyczne, psychologiczne, socjologiczne 
i medyczne starzenia się ludzi w Polsce (2012). Jak wskazują wyniki przeprowadzonego badania ${ }^{5}$, ponad 55\% ankietowanych w wieku co najmniej 80 lat zamieszkuje domy jednorodzinne, ponad $41 \%$ badanych - domy wielorodzinne, zaś 0,6\% - domy stałego pobytu. W przypadku osób w wieku 90 lat i więcej domy stałego pobytu zamieszkuje $1,1 \%$ respondentów. Istotny problem, zwłaszcza dla osób najstarszych, stanowią przeszkody architektoniczne. Istnienie barier utrudniających wyjście z domu wskazywało w badaniu $22,8 \%$ osób w wieku 80 lat i więcej. Ponadto wyniki badania świadczą o tym, że osoby starsze wykazują bierność, jeśli chodzi o modernizację swoich mieszkań (Bartoszek i in. 2012, s. 515-520). Seniorzy, niezależnie od warunków zamieszkania, rzadko decydują się na zamianę swojego obecnego mieszkania na mniejsze, tańsze w utrzymaniu i nowocześniejsze. Wśród seniorów istnieje silnie przywiązanie do zajmowanego środowiska mieszkaniowego.

Wobec powyższego obserwuje się stosunkowo niskie zainteresowanie inwestorów segmentem tzw. senior housing, co wynika m.in. z faktu, że na komercyjnym rynku nieruchomości mieszkaniowych większość nabywców lokali stanowią osoby młode, w wieku do ok. 40 lat. Ponadto w opinii pośredników w obrocie nieruchomościami grupa kupujących w wieku co najmniej 60 lat stanowi niewielki segment nabywców z uwagi na ograniczenia natury psychologicznej (niechęć do zmiany aktualnego miejsca zamieszkania) oraz ekonomicznej (ograniczenia w dostępie do środków pieniężnych - kredytów bankowych; por. Strączkowski i Celka 2012, s. 90-112).

Nie ulega jednak wątpliwości, że zarówno w warstwie teoretycznej (na gruncie nauki), jak i praktycznej (biorąc pod uwagę funkcjonowanie rynku mieszkaniowego oraz decyzje inwestorów) podjęcie prac w obszarze szeroko pojętych zachowań seniorów na rynku mieszkaniowym jest zasadne i konieczne, by: po pierwsze diagnozować sytuację mieszkaniową osób starszych oraz zaistniałe problemy, a po drugie - poszukiwać rozwiązań służących zarówno seniorom w ich codziennym życiu (usuwając niedogodności w mieszkaniach), jak i inwestorom, by ich nowe produkty mieszkaniowe mogły odpowiadać faktycznym potrzebom seniorów.

\section{Metodyka badania}

W celu przedstawienia sytuacji mieszkaniowej osób starszych, szczególnie w odniesieniu do tych momentów życia, które wiążą się ze słabościami i niedomaganiem, a które wymagają podjęcia trudnych decyzji związanych z mieszkaniem, przeprowadzono badania na lokalnym rynku w Poznaniu i okolicach, wśród

${ }^{5}$ Badanie zostało przeprowadzone na próbie 4813 respondentów w wieku 65 lat i więcej (Bartoszek i in. 2012, s. 512). 
seniorów - w większości osób uczęszczających na zajęcia do klubów seniora ${ }^{6}$. Podstawowe informacje dotyczące badania zaprezentowano w tabeli 1 .

Tabela 1. Podstawowe informacje dotyczące badania seniorów

\begin{tabular}{|l|l|}
\hline \multicolumn{1}{|c|}{ Kryterium } & \multicolumn{1}{c|}{ Charakterystyka } \\
\hline $\begin{array}{l}\text { Zakres rzeczowy } \\
\text { badania }\end{array}$ & $\begin{array}{l}\text { Podmiot badania - seniorzy, osoby w większości uczęszczające na zajęcia } \\
\text { organizowane w ramach klubów seniora. } \\
\text { Przedmiot badania - elementy mieszkania, które mogą sprawiać kłopot, } \\
\text { oceny mieszkania w stosunku do potrzeb oraz ewentualne decyzje dotyczące } \\
\text { mieszkania w sytuacji nagłej potrzeby }\end{array}$ \\
\hline $\begin{array}{l}\text { Zakres czasowy } \\
\text { badania }\end{array}$ & $\begin{array}{l}\text { Zakres czasowy badania pokrywa się z czasem gromadzenia materiału } \\
\text { w postaci ankiet i przypada na 2014 r. }\end{array}$ \\
\hline $\begin{array}{l}\text { Zakres } \\
\text { przestrzenny } \\
\text { badania }\end{array}$ & $\begin{array}{l}\text { Badanie dotyczy rynku poznańskiego, rozumianego nieco szerzej niż miasto } \\
\text { Poznań, gdyż część seniorów uczestniczy w zajęciach klubów seniora, } \\
\text { pomimo że mieszka poza Poznaniem. Uznano, że odpowiedzi osób mieszka- } \\
\text { jących poza miastem mogą być także cenną informacją }\end{array}$ \\
\hline $\begin{array}{l}\text { Dobór } \\
\text { i liczebność } \\
\text { próby }\end{array}$ & $\begin{array}{l}\text { Z uwagi na brak możliwości sporządzenia operatu losowania wykorzystano } \\
\text { dobór nielosowy, celowy, podyktowany dostępnością respondentów i moż- } \\
\text { liwościami pozyskania informacji. Ostatecznie liczebność próby sięgnęła } \\
\text { poziomu } n=410 \text { jednostek }\end{array}$ \\
\hline $\begin{array}{l}\text { Narzędzie } \\
\text { badawcze }\end{array}$ & $\begin{array}{l}\text { W zdecydowanej większości wykorzystano kwestionariusz ankiety audytoryj- } \\
\text { nej - podczas spotkań seniorów w klubach uczestnicy spotkań mogli w tym } \\
\text { samym czasie wypełnić ankietę. Umożliwiło to pozyskanie stosunkowo dużej } \\
\text { liczby ankiet podczas jednego spotkania }\end{array}$ \\
\hline
\end{tabular}

Źródło: opracowanie własne.

Jako uzupełnienie informacji zawartych w tabeli 1 należy podkreślić, że nastawienie respondentów do badania i wypełniania ankiet było generalnie pozytywne. Można było spotkać się zarówno z głosami zainteresowania tematyką, jak i opiniami o potrzebie tego rodzaju badań oraz zwracania uwagi na potrzeby mieszkaniowe osób starszych.

Jeśli chodzi zaś o samych respondentów i ich sytuację mieszkaniową, to należy dodać, że:

- zdecydowaną większość badanych stanowiły kobiety (81\%), co zapewne wynika z większej aktywności kobiet oraz większej niż u mężczyzn chęci wypełniania ankiety;

- blisko połowa (49\%) badanych to osoby w wieku do 69 lat, respondenci w wieku 70-79 lat stanowili odsetek na poziomie 39\%; tylko co dziesiąty badany $(11 \%)$ to senior w wieku 80 lat i więcej;

${ }^{6}$ Przedstawione tu rezultaty badań stanowią kolejne rozwinięcie problemu, który poruszany był w pracach (Strączkowski 2013, 2016). 
- połowa badanych to osoby z wykształceniem średnim, zaś $31 \%$ - to osoby z wykształceniem podstawowym lub zawodowym. Osoby z wykształceniem wyższym stanowiły $19 \%$ ogółu respondentów;

- większość badanych seniorów (64\%) swoją sytuację materialną ocenia (subiektywnie) jako przeciętną, blisko co trzeci (30\%) - jako raczej dobrą, a jako raczej złą - 6\%;

- sytuacja mieszkaniowa seniorów jest mocno zróżnicowana - seniorzy zamieszkują swoje obecne mieszkania przez wiele lat (średnio - 34 lata), połowa badanych (50\%) zamieszkuje lokale w budynkach wielorodzinnych bez windy, co trzeci respondent (34\%) - w bloku z windą, 3\% - w kamienicy, zaś 13\% - w domu jednorodzinnym;

- w większości badani mieszkają sami lub ze współmałżonkiem (łączny odsetek takich deklaracji wynosił 77\%, w tym 33\% osób deklarowało zamieszkiwanie z żoną lub mężem). Dość liczny jest także udział respondentów wskazujących na zamieszkiwanie z dziećmi i/lub wnukami (21\% ogółu pytanych);

- osoby z Poznania stanowiły $89 \%$ respondentów.

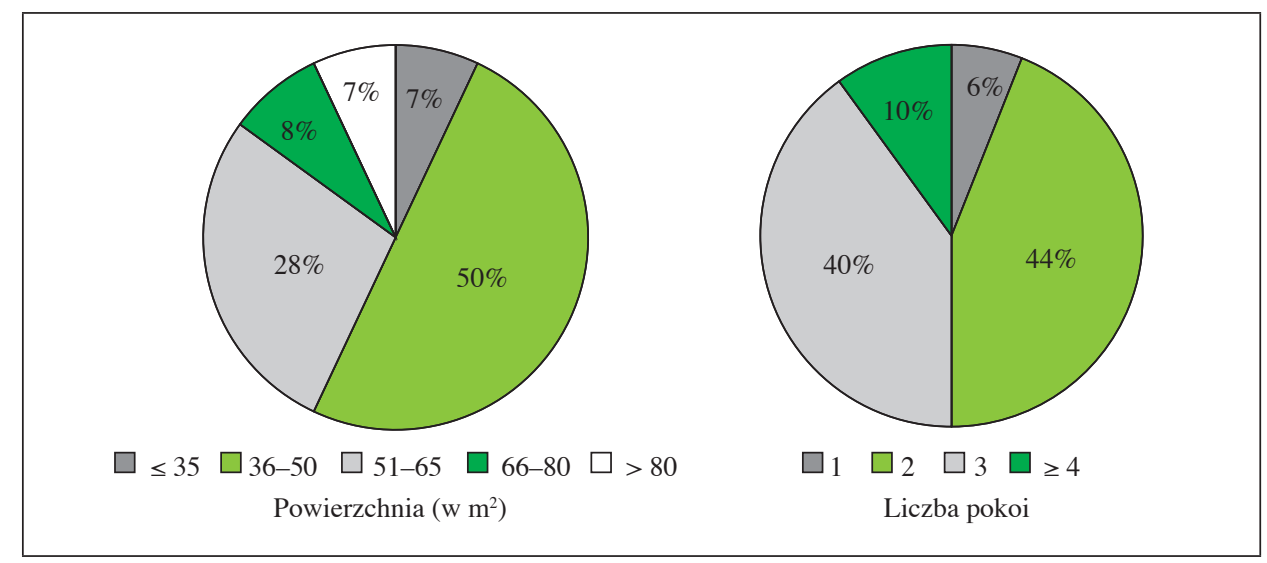

Rys 1 . Lokale zamieszkiwane przez badanych seniorów według powierzchni i liczby pokoi Źródło: opracowanie własne.

W przypadku lokali zamieszkiwanych przez badanych seniorów (rys. 1) zwrócić należy uwagę, że dominują metraże od 36 do $65 \mathrm{~m}^{2}$; połowa wszystkich lokali to jednostki o powierzchni od 36 do $50 \mathrm{~m}^{2}$, zaś $28 \%$ to jednostki o powierzchni od $51 \mathrm{do} 65 \mathrm{~m}^{2}$. Dużo rzadsze są mieszkania większe lub mniejsze od wymienionych.

Gdy pod uwagę weźmie się liczbę pokoi w lokalu, wyraźnie widać, że większość to mieszkania dwu-, trzypokojowe (odsetek na poziomie odpowiednio $44 \%$ i $40 \%)$. 


\section{Rezultaty badania}

Przedstawione poniżej rezultaty badania dotyczą trzech ogólnych problemów:

- dopasowania mieszkania do obecnych potrzeb seniora,

- określenia barier (niedogodności), które są odczuwane w mieszkaniu seniora,

- decyzji, którą trzeba będzie podjąć w sytuacji, gdy pojawią się problemy zdrowotne lub wynikające z niedomagań fizycznych i senior będzie potrzebować pomocy.

Z uwagi na dość duży zakres danych oraz ograniczoną objętość artykułu struktury odpowiedzi respondentów zaprezentowane zostały w tablicach kontyngencji oraz na rysunku, z uwzględnieniem takich kryteriów segmentacyjnych jak zamieszkiwanie seniora (z co najmniej jedną osobą lub samodzielne) i wiek seniora (do 69 lat oraz 70 lat i więcej).

Pierwszą kwestią, jaką poruszono w trakcie badania, było dopasowanie wielkości mieszkania (pod względem powierzchni i liczby pokoi) do obecnych potrzeb seniora, a także określenie, czy wejście na piętro, na którym znajduje się lokal, sprawia problem (tabela 2).

Tabela 2. Dopasowanie mieszkania do bieżących potrzeb seniora (w \%)

\begin{tabular}{|c|c|c|c|c|c|c|}
\hline \multirow[b]{2}{*}{$\begin{array}{l}\text { Wyszcze- } \\
\text { gólnienie }\end{array}$} & \multirow[b]{2}{*}{ Odpowiedzi } & \multirow[b]{2}{*}{ Ogółem } & \multicolumn{2}{|c|}{ Zamieszkiwanie } & \multicolumn{2}{|c|}{ Wiek } \\
\hline & & & $\begin{array}{c}\text { z co } \\
\text { najmniej } \\
\text { jedną osobą }\end{array}$ & $\begin{array}{c}\text { samodziel- } \\
\text { nie }\end{array}$ & do 69 lat & $\begin{array}{l}70 \text { lat } \\
\text { i więcej }\end{array}$ \\
\hline \multirow{3}{*}{$\begin{array}{l}\text { Powierzchnia } \\
\text { mieszkania } \\
\text { w stosunku } \\
\text { do potrzeb }\end{array}$} & za duża & 7,6 & 6,8 & 8,5 & 7,7 & 8,1 \\
\hline & odpowiednia & 83,6 & 83,3 & 85,3 & 80,0 & 86,4 \\
\hline & za mała & 8,8 & 9,9 & 6,2 & 12,3 & 5,6 \\
\hline \multirow{3}{*}{$\begin{array}{l}\text { Liczba pokoi } \\
\text { w lokalu } \\
\text { w stosunku } \\
\text { do potrzeb }\end{array}$} & za duża & 7,4 & 7,3 & 6,8 & 7,2 & 8,1 \\
\hline & odpowiednia & 83,8 & 82,3 & 87,6 & 79,9 & 86,9 \\
\hline & za mała & 8,8 & 10,5 & 5,6 & 12,9 & 5,1 \\
\hline \multirow{4}{*}{$\begin{array}{l}\text { Czy wejście } \\
\text { na piętro } \\
\text { sprawia } \\
\text { problem }\end{array}$} & tak & 14,0 & 13,2 & 14,8 & 12,4 & 16,2 \\
\hline & raczej tak & 13,1 & 13,7 & 11,9 & 10,4 & 16,2 \\
\hline & raczej nie & 22,9 & 19,2 & 27,3 & 22,8 & 23,7 \\
\hline & nie & 50,0 & 53,9 & 46,0 & 54,4 & 43,9 \\
\hline
\end{tabular}

Źródło: opracowanie własne.

W odniesieniu do powierzchni zdecydowana większość seniorów (prawie $84 \%$ ) oceniła, że metraż mieszkania jest zgodny z ich potrzebami. Zaledwie ok. $9 \%$ badanych wskazało, że jest on zbyt mały, a mniej niż $8 \%$ że zbyt duży. Niewielkie różnice uwidaczniają się pod tym względem w zależności od tego, czy 
senior mieszka samodzielnie, czy z inną osobą (mąż, żona i lub dzieci). W pierwszym przypadku (gdy osoba starsza mieszka samotnie) - odsetek stwierdzeń, że powierzchnia zajmowanego lokalu jest za duża, wyniósł ok. 9\% (wobec prawie $7 \%$ w przypadku, gdy w lokalu mieszka jeszcze co najmniej jedna osoba). Gdy w lokalu mieszkają inne osoby, wzrasta odsetek seniorów stwierdzających, że powierzchnia mieszkania jest zbyt mała w stosunku do ich potrzeb. Nieco inaczej kwestia dopasowania mieszkania do bieżących potrzeb wiąże się z wiekiem badanych. U osób relatywnie młodszych (do 69 lat) odnotowuje się wyższy odsetek odpowiedzi, że powierzchnia jest zbyt mała (ponad 12\%). U osób starszych zaobserwowano nieco wyższy udział stwierdzeń, że metraż jest zbyt duży (ok. 8\%).

W przypadku liczby pokoi w stosunku do potrzeb, podobnie jak w poprzedniej kwestii, większość badanych (prawie 84\%) uważa, że w zamieszkiwanym lokalu liczba pokoi odpowiada ich potrzebom. W zasadzie tylko współdzielenie lokalu z innymi osobami (głównie dziećmi czy wnukami) jest przesłanką, by stwierdzić, że liczba pokoi jest zbyt mała.

Jeśli zaś chodzi o odczuwanie problemów związanych z wejściem na piętro, gdzie usytuowany jest lokal, ok. $73 \%$ osób stwierdziło, że nie stanowi to problemu. Przeciwnego zdania jest $27 \%$ badanych. Warto jednak zauważyć, że problemu nie odczuwają często te osoby, które mieszkają w budynkach z windą lub na tzw. niskich piętrach (parter lub pierwsze piętro) oraz są relatywnie młodsze (odsetek osób w wieku do 69 lat wskazujących na problem z wejściem na piętro wyniósł prawie $23 \%$, w przypadku osób starszych było to ponad $32 \%$ ).

Kolejna badana kwestia dotyczyła odczuwanych w mieszkaniu barier. Zostały one zaprezentowane w tabeli 3. Największy problem stanowi dla osób starszych wejście do wanny (ponad 41\%), najmniejszy zaś wiąże się z powierzchniami podłóg (ok. 16\%). Rozpatrując dane zaprezentowane w tabeli 3, można powiedzieć, że wraz z wiekiem odczuwanie niedogodności związanych z brakiem uchwytów (np. w łazience) czy wysokimi progami wzrasta (co naturalne). Zastanawiające jest jednak to, że w sytuacji samodzielnego zamieszkiwania odsetki wskazań na poszczególne niedogodności są stosunkowo niższe. Być może związane jest to z tym, że mieszkania te są lepiej dopasowane do potrzeb seniorów, a być może w takiej sytuacji nie myśli się o problemach lub celowo ich nie zauważa.

Na rys. 2 oraz w tabeli 4 zaprezentowano rezultaty badań w trzecim badanym zakresie, dotyczącym hipotetycznej sytuacji, w której seniorzy będą potrzebować pomocy. Z deklaracji seniorów wynika, że zdecydowanie pragną oni pozostawać w swoich domach, licząc na opiekę i pomoc rodziny, innych bliskich osób lub instytucji. Przeprowadzenie się do innego miejsca traktowane jest jako ostateczność. Co ciekawe, wyższe odsetki wskazań zaobserwowano w tym względzie zarówno u osób mieszkających z rodziną (ci seniorzy traktują za naturalne dalsze mieszkanie z bliskimi), jak i u osób starszych - w wieku powyżej 70 lat. 
Tabela 3. Bariery odczuwane przez seniorów w zajmowanych przez nich mieszkaniach (w \%)

\begin{tabular}{|c|c|c|c|c|c|}
\hline \multirow[b]{2}{*}{ Bariery } & \multirow[b]{2}{*}{ Ogółem } & \multicolumn{2}{|c|}{ Zamieszkiwanie } & \multicolumn{2}{|c|}{ Wiek } \\
\hline & & $\begin{array}{c}\text { z co } \\
\text { najmniej } \\
\text { jedną osobą }\end{array}$ & $\begin{array}{c}\text { samodziel- } \\
\text { nie }\end{array}$ & do 69 lat & $\begin{array}{l}70 \text { lat } \\
\text { i więcej }\end{array}$ \\
\hline Wysokie progi & 18,4 & 21,1 & 15,3 & 15,6 & 21,3 \\
\hline $\begin{array}{l}\text { Brak uchwytów } \\
\text { (np. w łazience) }\end{array}$ & 36,5 & 38,5 & 35,0 & 35,1 & 39,3 \\
\hline $\begin{array}{l}\text { Za wąskie futryny } \\
\text { w drzwiach }\end{array}$ & 19,7 & 22,7 & 16,4 & 19,0 & 21,5 \\
\hline $\begin{array}{l}\text { Śliskie powierzchnie } \\
\text { podłogi }\end{array}$ & 16,4 & 19,0 & 13,3 & 14,7 & 19,4 \\
\hline Wejście do wanny & 41,4 & 38,0 & 45,1 & 39,7 & 45,1 \\
\hline $\begin{array}{l}\text { Zbyt wysoko zawieszone } \\
\text { szafki }\end{array}$ & 27,2 & 27,2 & 26,5 & 25,8 & 29,0 \\
\hline
\end{tabular}

Źródło: opracowanie własne.

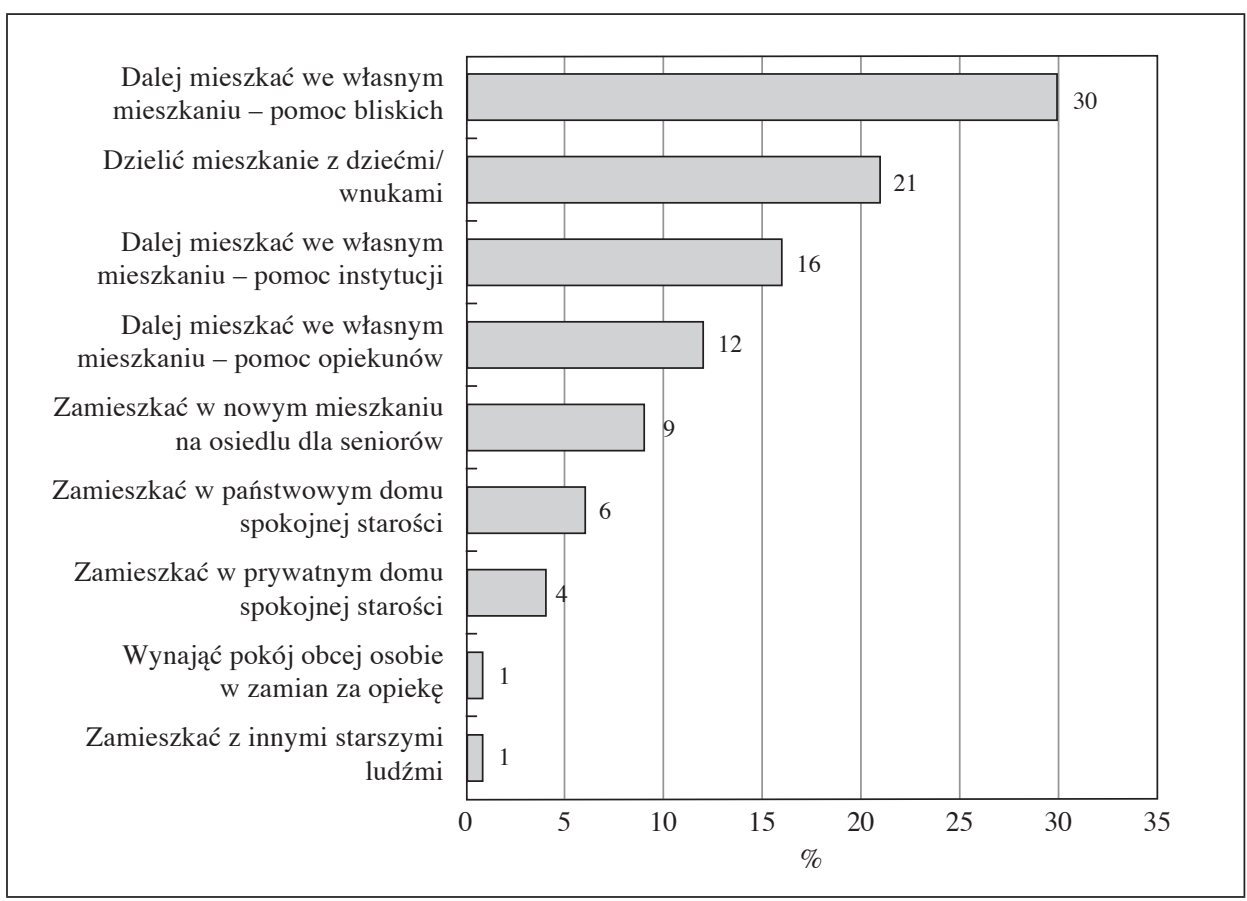

Rys. 2. Deklaracje seniorów dotyczące mieszkania w sytuacji, gdy pojawi się problem (np. zdrowotny) i zaistnieje potrzeba pomocy

Źródło: opracowanie własne. 
Tabela 4. Deklaracje seniorów dotyczące mieszkania w sytuacji, gdy pojawi się problem (np. zdrowotny) i zaistnieje potrzeba pomocy - według zamieszkiwania i wieku (w \%)

\begin{tabular}{|c|c|c|c|c|}
\hline \multirow[b]{2}{*}{ Wybrany wariant } & \multicolumn{2}{|c|}{ Zamieszkiwanie } & \multicolumn{2}{|c|}{ Wiek } \\
\hline & $\begin{array}{c}\text { z co } \\
\text { najmniej } \\
\text { jedną } \\
\text { osobą }\end{array}$ & $\begin{array}{l}\text { samo- } \\
\text { dzielnie }\end{array}$ & do 69 lat & $\begin{array}{c}70 \text { lat } \\
\text { i więcej }\end{array}$ \\
\hline Dalej we własnym mieszkaniu - pomoc bliskich & 29,9 & 31,1 & 28,5 & 31,2 \\
\hline Dzielić mieszkanie z dziećmi/wnukami & 29,1 & 13,2 & 17,5 & 23,0 \\
\hline Dalej we własnym mieszkaniu - pomoc instytucji & 7,7 & 21,3 & 15,6 & 16,7 \\
\hline Dalej we własnym mieszkaniu - pomoc opiekunów & 14,1 & 11,5 & 12,3 & 12,0 \\
\hline $\begin{array}{l}\text { Zamieszkać w nowym mieszkaniu na osiedlu } \\
\text { dla seniorów }\end{array}$ & 9,4 & 8,4 & 14,1 & 5,5 \\
\hline Zamieszkać w państwowym domu spokojnej starości & 4,6 & 7,7 & 6,0 & 5,8 \\
\hline Zamieszkać w prywatnym domu spokojnej starości & 2,2 & 6,2 & 2,4 & 4,8 \\
\hline Wynająć pokój obcej osobie w zamian za opiekę & 1,3 & 0,8 & 1,6 & 0,6 \\
\hline Zamieszkać z innymi starszymi ludźmi & 1,3 & 0,3 & 1,4 & 0,5 \\
\hline Razem & 100,0 & 100,0 & 100,0 & 100,0 \\
\hline
\end{tabular}

Źródło: opracowanie własne.

$\mathrm{Z}$ drugiej strony u stosunkowo młodszych seniorów można zauważyć większą akceptację osiedli budowanych z myślą o seniorach oraz mieszkanie z innymi ludźmi (także seniorami) w zamian za opiekę. Warto też dodać, że samodzielne mieszkanie wiąże się z wyższym wskaźnikiem akceptacji zamieszkania w domu spokojnej starości - prywatnym lub państwowym (por. tabela 4).

\section{Zakończenie}

Problem starzenia się społeczeństwa jest coraz bardziej widoczny. Wymaga on głębokiej refleksji i poszukiwania rozwiązań, bo choć dzisiejsi seniorzy stosunkowo pozytywnie oceniają swoją sytuację mieszkaniową, to dostrzegają pewne trudności i bariery, które z czasem mogą się pogłębiać. Warto podkreślić, że seniorzy są przywiązani do swojego miejsca zamieszkania i generalnie nie chcą go zmieniać, nawet w sytuacji potrzeby. Uzyskane wyniki badań dotyczą jednak sytuacji hipotetycznej, przed którą respondenci jeszcze nie stanęli, a więc można powiedzieć, że związane są z warunkami „tu i teraz”, nie zaś z realną decyzją dotyczącą konkretnej, trudnej sytuacji.

Należy poszukiwać rozwiązań optymalnych z punktu widzenia seniorów, ich potrzeb i możliwości ich zaspokojenia. Być może konieczne będzie określenie 
nowych kierunków w budownictwie mieszkaniowym oraz znalezienia takich koncepcji dla seniorów, które zaspokoją także potrzebę ich bycia z młodszymi pokoleniami.

\section{Literatura}

Aspekty medyczne, psychologiczne, socjologiczne i medyczne starzenia się ludzi w Polsce (2012), red. M. Mossakowska, A. Więcek, P. Błędowski, Termedia Wydawnictwa Medyczne, Poznań.

Bartoszek A., Niezabitowska E., Kucharczyk-Brus B., Niezabitowski M. (2012), Warunki zamieszkiwania seniorów. Główne ustalenia badawcze (w:) Aspekty medyczne, psychologiczne, socjologiczne i ekonomiczne starzenia się ludzi w Polsce, red. M. Mossakowska, A. Więcek, P. Błędowski, Termedia Wydawnictwa Medyczne, Poznań.

Deniszczuk L. (2001), Warunki życia starszych ludzi w Polsce (w:) Mieszkania starszych ludzi w Polsce. Sytuacja i perspektywy zmian, red. H. Zaniewska, Wydawnictwo A-ZET Sp. z o.o., Warszawa.

Król M. (2014), Starzenie się ludności Polski, „Przegląd Nauk Stosowanych”, nr 4.

Mieszkania starszych ludzi w Polsce. Sytuacja i perspektywy zmian (2001), red. H. Zaniewska, Wydawnictwo A-ZET Sp. z o.o., Warszawa.

Migracje zagraniczne ludności (2016), GUS, http://stat.gov.pl/obszary-tematyczne/ludnosc/migracje-zagraniczne-ludnosci/ (data dostępu: 17.06.2017).

Narodowy Spis Powszechny 2002 - wyniki (2003), GUS, http://stat.gov.pl/spisy-powszechne/narodowe-spisy-powszechne/narodowy-spis-powszechny-2002/ (data dostępu: 17.06.2017).

Obraz typowego Polaka w starszym wieku (2010), CBOS, Warszawa.

Rocznik demograficzny 2016 (2016), GUS, http://stat.gov.pl/obszary-tematyczne/roczniki-statystyczne/roczniki-statystyczne/rocznik-demograficzny-2016,3,10.html (data dostępu: 16.05.2017).

Rosset E. (1959), Proces starzenia się ludności. Studium demograficzne, Polskie Wydawnictwa Gospodarcze, Warszawa.

Rysz-Kowalczyk B., Szatur-Jaworska B. (2004), Polityka społeczna wobec cyklu życia. Faza starości (w:) Nasze starzejące się społeczeństwo. Nadzieje i zagrożenia, red. J.T. Kowaleski, P. Szukalski, Wydawnictwo Uniwersytetu Łódzkiego, Łódź.

Strączkowski Ł. (2013), Postawy mieszkaniowe klientów-seniorów w świetle badań lokalnego rynku mieszkaniowego, „Studia Ekonomiczne Uniwersytetu Ekonomicznego w Katowicach", nr 155.

Strączkowski Ł. (2016), Mieszkania seniorów w świetle badań lokalnego rynku mieszkaniowego, „Biuletyn Stowarzyszenia Rzeczoznawców Majątkowych Województwa Wielkopolskiego", vol. 46, $\mathrm{nr} 2$.

Strączkowski Ł., Celka K. (2012), Opinie pośredników o stanie rynku mieszkaniowego, preferencjach klientów i możliwościach ich realizacji (w:) Potrzeby mieszkaniowe na lokalnym rynku nieruchomości mieszkaniowych $i$ sposoby ich zaspokajania (raport z badan ankieotwych), Katedra Inwestycji i Nieruchomości, Uniwersytet Ekonomiczny w Poznaniu, Poznań.

Sytuacja demograficzna osób starszych i konsekwencje starzenia się ludności Polski w świetle prognozy na lata 2014-2050 (2014), GUS, Warszawa. 
Szukalski P. (2012), Solidarność pokoleń. Dylematy relacji międzypokoleniowych, Wydawnictwo Uniwersytetu Łódzkiego, Łódź.

Tablice trwania życia 1990-2015 (2016), GUS, http://stat.gov.pl/obszary-tematyczne/ ludnosc/trwanie-zycia/trwanie-zycia-tablice,1,1.html (data dostępu: 17.06.2017).

Warunki mieszkaniowe gospodarstw domowych i rodzin 2002 (2003), GUS, Warszawa.

\section{Seniors' Housing Conditions and Their Decisions on the Local Housing Market}

(Abstract)

According to experts, continuous population aging will bring about numerous changes on the housing market. There is widening discussion on the provision of adequate care for the elderly, matching housing to seniors' preferences and expectations, and decisions related to the prospective changes of their housing conditions and the choice of a new home. The paper contributes to the debate, showing the housing situation of older people. In order to achieve the aim, a questionnaire survey was conducted among senior citizens examining their housing situation.

The research findings show that seniors want to age in place as long as possible with the assistance of formal or informal helpers. Moreover, younger groups of seniors tend to be more open to living in senior housing estates as well as for co-housing in exchange for help. Seniors that live independently would rather move into a nursing home, either private or public.

Keywords: seniors, housing market, demographic aging, senior housing. 